酵素による大豆蛋白質の構造研究, 大豆蛋白質のゲル の物性について解説された.

\section{魚肉蛋白質のゲル化上智大理工 土屋隆英} 魚肉蛋白質のゲル化におけるアクトミオシン，ミオシ ン, アクチンの役割について，魚肉蛋白質ゾルの昇温に 伴う動的粘弾性の測定，電子顕微鏡による組織観察など により説明された.

酵素修飾による蛋白質のゲル形成

味の素 本木正雄

蛋白質を修飾する酵素について概説，とくにトランス グルタミナーゼによる修飾反応，蛋白質溶液のゲル化に ついて解説された.

ハイドロコロイドの感覚特性

大妻女大家政 青木 宏

ハイドロコロイドは主としてテクスチャーに影響を与 えるので, 食品のテクスチャー全般について, 研究方 法, 測定法，また，テクスチャーと啫好について解説さ れた。

ハイドロコロイドの調理特性

日本女大家政 中浜信子 調理の中でハイドロコロイドの果たす役割，澱粉糊夜 の保温性, ゲル化, ブランマンジェの力学的性状などに ついて解説された。

総合討論

ハイドロコロイドは物質としてとらえるよりゲル状 態，エマルション状態あるいはもっと一般的な分散状態 としてとらえるほうが良い，汼粉の老化についての研究 の現状，方法論に関して，議論が続いた，とくに，高橋 幸資氏（農工大），中沢文子氏（共立女子大）よりコメン トがあった。

なお，講演要旨集（64.ページ）はまだ残部があるの

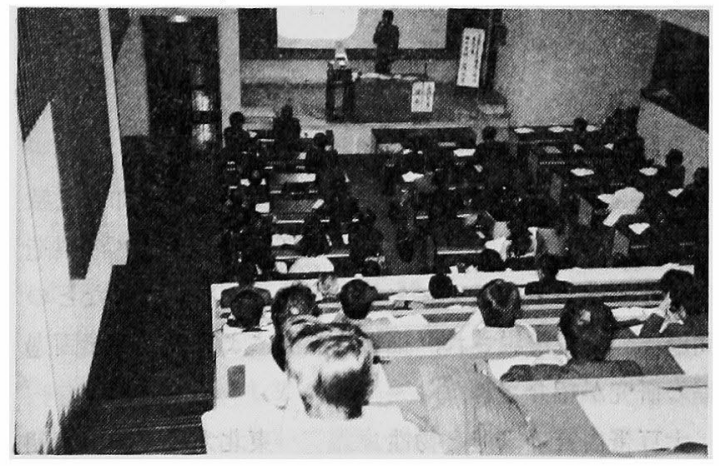

会場風景
で, ご希望の方は 2200 円（送料込み）を同封のうえ， 下記へお申し込み下さい。

本研究小集会は農芸化学会の藪田基金補助により可能 となったもので, 記して謝意を表する次第である.

（要旨集申し込又先）

茨城県つくば市観音台 2-1-2

農林水産省 食品総合研究所 計測工学研究室

西成勝好

TEL 02975-6-8031

\section{藪田セミナー「C-P 化合物の代謝と}

\section{機能」報告}

世話人 堀口雅昭 (東北大学農学部)

標記のセミナーが昭和 63 年 11 月 5 日（土）午後 1 時から 6 時まで, 東北大学医学部・艮陵会館で開催され た. C-P 化合物とは，文字どおり C原子と $\mathrm{P}$ 原子の共有 結合を含む化合物のことである. 生理活性 C-P 化合物 の設計と有機合成の研究は, 米国, フランス, ポーラン ド，ソ連などで盛んであり，また，わが国でも注目すべ き研究が進められている、しかし，今回の七ミナーでの 主題は，生体物質としての C-P 化合物に限定された。 講師には, 有機分析化学の林陽（近畿大学理工学部 教授), 抗生物質の瀬戸治男 (東京大学応用微生物研究 所教授), 脂質生化学の板坂 修 (滋賀大学教育学部教 授), 神経化学の佐武 明 (新潟大学脳研究所教授) 捄よ び生体膜生化学の野沢義則 (岐阜大学医学部教授) の 5 名の先生を扮願いした.

はし゚めに, 農芸化学会東北支部長 足立 達 東北大 教授から, 薮田セミナーの趣旨と農芸化学の土壌におけ る C-P 化合物の芽生えに触れた開会のあいさつがあっ た. 次に世話人が，C-P 化合物の代謝と食物連鎖に関す る 30 分の話の中で, この 30 年間の世界の研究の流れ を紹介したそして，各講師から45 分ずつ，それぞれ の専門分野における研究の現状と問題点が要約され，ま た質疑応答があって，予定を 20 分過ぎて閉会した。

C-P 化合物に関しては, 1967 年の国際生化学会議 （東京）のコロキウムおよび 1970 年の日本生化学会大会 のシンポジゥムのテーマとしてとりあげられたことか゚あ る.しかし，農芸化学会関係に拈ける集まりは今回が初 めてであった. 会場が農学部から離れていたためか, 学 
生・院生の若い资が少ないのは成念で荡った。店が，参 会者は 11 大学 1 研究所加ら 40 名に達した。 セミナー

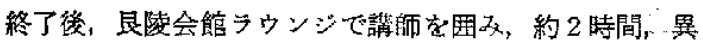
分野の研究蓄の間で交流の害をあげることができて有意 義であった。

\section{【講演要旨]}

1. 食物連鎖上 C-P 化合物 . 東北大農 堀口雅昭 [座長 伊崎和夫 冥北大農]

C-P 化合物はホスホエノールピルビン酸の分子内転 䔟反応で合成される。この合成能は，分裂菌頑，真菌植 物，原生動物，些腸動物，軟体動物士上の生物准化系統 樹上で低位の生物に偪っているらしい，現在，30以上の

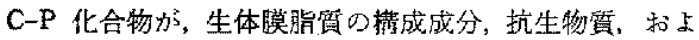
びこれらの代㛛関連物蓓として同定されている。これら のうる，20以上の化合物肪わが国で発見された，木ス木 ン酸とホスフィン酸の2群他大別されるが，その多くは

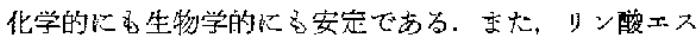
テルやカル酸の代謝醉素の基筫にもなるので，食物 連鎖を通し，多種類の到物体队洺行し，ホスホノリピ ドや胆汁酸程上して落俵している。CP結合の分解の主 役怯䋛脈でする。

2. ホスホ，脂質の分析法一一質量分析を巾心として 近嘓大理工 林 踼

[座最 目黑 熙 果北大農]

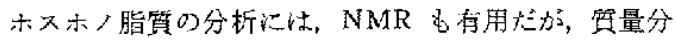

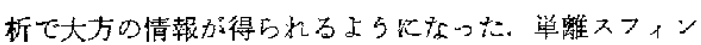

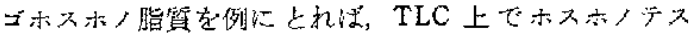

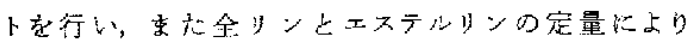

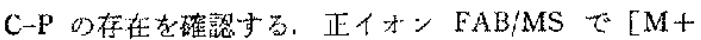

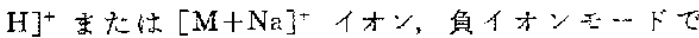
[M- - H] イオン加生成するので，分子量を決定で学る。 次に，負个オンヒードで $m / z 124$ 扰よび 138 のピーク

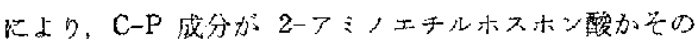

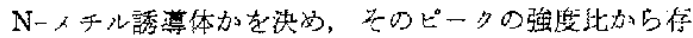
在量を知りらる。 また，正イオン $\mathrm{FAB} / \mathrm{MS}$ から長鎖塩 基イオン，七シミドイオンが得られ，它の差加ら脂肪酸 組成屯わかる，さらに，正負イオン FAB/MS から糖の

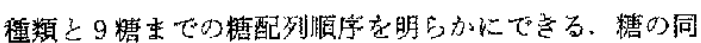
定は化学的方法と GCに上り，また，グリンド結合の

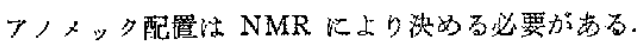

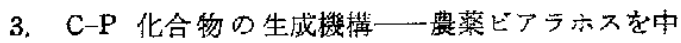
心をして
東大応微研・瀬戸沿男

[辰唇 山下恭平 束北大農]

強为な除草成ビアラホス(ホスフィノトリシル・アラ ニル・アラニン) の生産性を高好目的之，并の C-P-

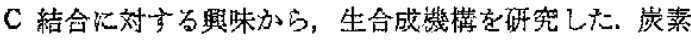
骨格の由来は ${ }^{13} \mathrm{C}$ 化合物の取远みで調ぺた。 反応中閭体

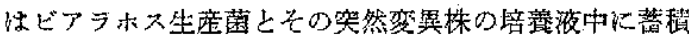
寸る C-P 化合物 ${ }^{11} \mathrm{P}-\mathrm{NMR}$ で追跡し，同定した. 并 の結果，木スホニノ・ルピルビン酸2分子上了セチル CoA から 10 段階以上の反応でデメ゙ルホスフィノトリ シンが生成し，さらに 4 段階の反灾を経てビアラホスが

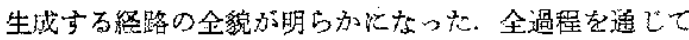

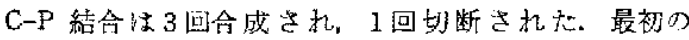
C-P 結合合成に闺与するホスホムノールピルビン酸亦 スホムターゼを精亦し，その醭索化学的性質とN末端つ

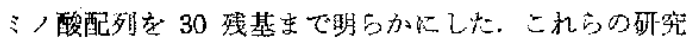
過程で $\mathrm{P}-\mathrm{H}$ 結合の生体での存在が初めて明らかにされ

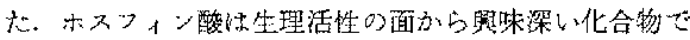
志る。

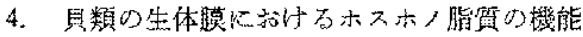
滋賀大教育 板坟 修 〔庵唇 玉利正人 脣陭大教育] 貝類のスフィンダリン脂質にはせラミドー2ーアミノュ

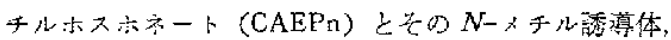
スフィソゴミニリン，七ラミドー六スホエタノールマミ

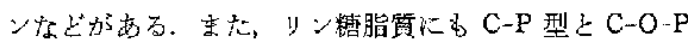
型の网苦方饬及.しかし、生体膜てのこれらの機能は 汪上んどかかっていない，CAEPn に対し特異性の高い 抗体を作り，これ老用いて，貝類スッィンゴ脂䁈中の

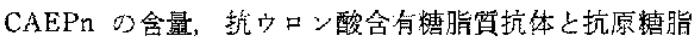

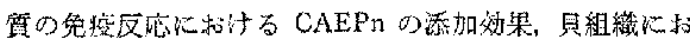
ける CAEPnの分布沈どを調べた。れらの研究によ口

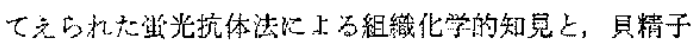
由来のらロソ酸含有精脂質のリポソームム中での抗原-抗 体反地加 CAEPn 比上り活性化される現象红ついて考察

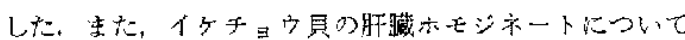
CAEPn の合成経路の大筋起明らか心した。

5, C-P 含有糖脂筫亡神程㙨能

新潟大脳研 佐武明

〔來長 杉田陸海 滋贺大教育〕 媨全体のごく一部を满成する汇すざない神経細胞体の

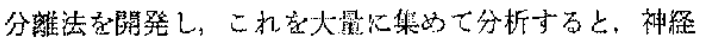


細胞体はセレブロシドとサルファタイドを含むという通

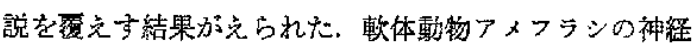
線維性ミエリンを欠くので，予想ど物りセレプロシドと サルファタイドを含まず, シフリン酸もなく，CAEPn が見つかった，その皮虞から数種の C-P 含有糖脂筫を

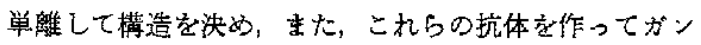
グリオンなどを染めたガングリオン，神経楾維中には

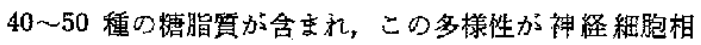

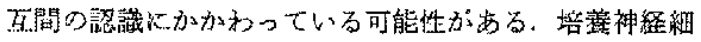
胞の突起の伸長化効果があるガングリオンドす見出され ている. C-P 含有縟脂質がこれらの生物学的活性火一役 買っている可能性む否定できない，しかし，試駼管内で えた結果を生体に资すに際しては，慎重さが要求され る.

6。生体膜の環境遵応とホスホ>䁕質 肢皁大医 野沢義則 [巫長 神尾好是 東北大豊]
単細胞動物テトラヒメナは，生体膜合成のモデル細胞

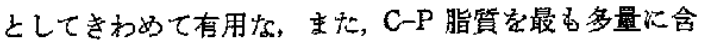
む生物である. その膜系を系絠的飞分別して調へるを，

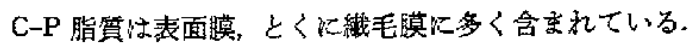

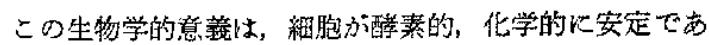
ることから，同じ単細胞生物である細菌やカビがるつ細

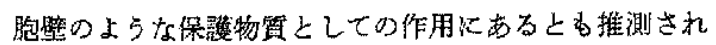
ている.テトラヒメナを種々の脂質、アルコールの存在

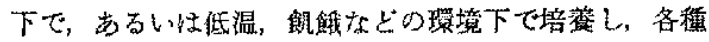
の膜について成分分析, 流動性測定, 電顕観察を行一

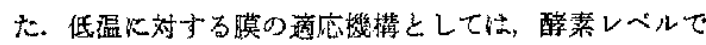
の誝尊による脂肪酸不飽和化醅素の增加，ジシル型 C-P 脂質の堌加，およびこの脂霔の中への多価不飽和脂 肪酸の取り迟み上よる可能性が考えられる。

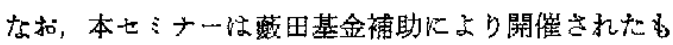
ので，記して謝意意する次第で方る。 